\title{
GENETIC ANALYSIS OF SOMATIC CELL COUNT AND MILK YIELD TRAITS IN EGYPTIAN BUFFALO
}

\author{
Manal M. El-Bramony, I. A. Gebreel and Set El-Habaeib S. Awad \\ Animal Production Research Institute, Ministry of Agriculture and Land \\ Reclamation, Dokki, Giza, Egypt
}

\section{SUMMARY}

The objective of this study was to investigate the association between milk, fat and protein yields with somatic cell count in milk, and to study possibilities for improving the performance of the Egyptian buffalo. A total of 1408 lactation records for somatic cell count and milk yield traits, representing 702 buffalo cows daughter of 103 sires and 544 dams, were analyzed by fitting a multiple-trait repeatability animal model using the restricted maximum likelihood (REML) procedure. The model included herd-year-season of calving and age nested within parity for the first five parties as fixed effects while additive genetic and permanent environment were used as random effects. All fixed effects contributed significantly $(P<0.0001)$ to variations in all traits. The average lactation yields $( \pm S D)$ of milk, fat and protein $(\mathrm{kg})$ and lactation measure of somatic cell count were 1402 (645), 94.9 (46.5), 53.6 (24.2), and 4.79 (0.31), respectively. Heritability estimates for lactation yields of milk, fat and protein and somatic cell count were $0.16,0.12,0.15$ and 0.27 , respectively. The corresponding repeatability estimates were 0.52, 0.50, 0.51 and 0.38. Phenotypic and genetic correlations between all yield traits were positive and high (0.95 to 0.99). Correlations between lactation somatic cell count (LSCC) and milk yield traits were low (-0.29 to 0.01). Therefore, a selection program to improve milk yield is expected to result in a favourable response in other milk yield traits without a negative effect on udder health for the Egyptian buffalo.

Keywords: lactation measure, fat and protein yields, selection, udder health

\section{INTRODUCTION}

Mastitis is the most costly diseases in dairy production; hence, reducing mastitis incidence is important for economic, environmental and animal welfare reasons. In dairy cattle, selection for milk yield alone causes negative effects on udder health (Emanuelson et al., 1988; Mrode and Swanson, 1996 and Heringstad et al., 2003). Somatic cell score could be used as an indirect selection criterion for mastitis incidence, as is widely done in dairy cattle (Coffey et al., 1986; Mrode and Swanson, 1996 and Rodriguez-Zas et al., 2000). Somatic cell count is relatively easy to record and has a higher heritability than mastitis incidence (Mrode and Swanson, 1996). Estimates reported for the heritability of lactation measures of somatic cell count ranged from 0.12 to 0.39 (Kadarmideen and Pryce, 2001; De Ross et al., 2003 and Weller and Ezra, 2004) for dairy cattle.

Issued by The Egyptian Society of Animal Production 
In Egypt, where there is lack of national database on resistance for diseases such as mastitis, SCC becomes very important as a tool for reducing mastitis incidence (El-Bramony et al., 2004a). Therefore, estimating genetic parameters of somatic cell count and milk yield traits seems essential. The aim of the present study was to investigate the association between milk, fat and protein yields with somatic cell count, in the first five lactations and to study possibilities of improving performance the Egyptian buffalo.

\section{MATERIALS AND METHODS}

\section{Description of the data set:}

Data used in this study were collected at monthly intervals over the period from October 1999 through November 2008 from four buffalo experimental herds belonging to the Animal Production Research Institute (APRI), Ministry of Agriculture and Land Reclamation. Test day (TD) records for milk yield, fat and protein percentages were measured following an alternative am-pm monthly recording scheme. Then, milk yield traits per lactation were estimated and adjusted to 305-d using Fleischmann's method (Barillet, 1985). Buffalo cows with less than 3 TD records per lactation were excluded from the data. The maximum number of test day records per lactation was 10 records.

Fat and protein percentages were measured by the automated method of infrared absorption spectrophotometry (Milk-o-Scan; Foss Electric, Hiller dd, Denmark), and SCC was determined by the floro-opto-electronic cell counting (Fossomatic, Foss Electric, Hiller $\phi$ d, Denmark), both at the Dairy Services Unit, Animal Production Research Institute, Sakha, Kafr El-Sheikh Governorate. Some of the buffalo cows were hand milked while others were machine milked. Milking was practiced twice a day at 7 am and $4 \mathrm{pm}$ throughout the lactation period. TD records for SCC were transformed to their logarithmic form $\left(\log _{10} \mathrm{SCC}\right)$ in an effort to normalize their distribution (Ali and Shook, 1980). The lactation measure of SCC (LSCC) was the mean of test day $\log _{10}$ SCC corrected for days in milk, age at calving and milking type as suggested by Wiggans and Shook (1987). A total of 1408 lactation records of milk yield traits and SCC for 702 buffalo cows, daughter of 103 sires and 544 dams were used in the study. Data were classified according to the month of calving into two seasons: hot (April through September) and mild for the rest of months. All known relationships among individuals were considered in the animal model.

\section{Statistical analysis:}

Genetic parameters were estimated by the Restricted Maximum Likelihood (REML) procedure, using the software VCE 4.0 (Groeneveld and García Cortés, 1998), fitting a multiple-trait repeatability animal model and incorporating all available pedigree information. The following multiple-trait animal model was employed to analyze somatic cell count and milk yield traits:

$\mathrm{Y}_{\mathrm{ijklmn}}=\mu+\mathrm{A}_{\mathrm{i}}+\mathrm{Pe}_{\mathrm{j}}+\mathrm{HYS}_{\mathrm{k}}+\mathrm{P}_{1}+\mathrm{AWP}_{\mathrm{m}}+\mathrm{e}_{\mathrm{ijklmn}}$ where:

$\mathrm{Y}_{\mathrm{ijklm}}=$ the record of (305-d milk yield, 305-d fat yield, 305-d protein yield and lactation measure of SCC); 
$\mu \quad=$ the overall mean,

$\mathrm{A}_{\mathrm{i}} \quad=$ the additive genetic random effect of buffalo, assumed to be NID $\left(0, \sigma^{2}{ }_{\mathrm{a}}\right)$;

$\mathrm{Pe}_{\mathrm{j}}=$ the permanent environment random effect on the buffalo assumed to be $\operatorname{NID}\left(0, \sigma_{\mathrm{pe}}^{2}\right)$;

$\mathrm{HYS}_{\mathrm{k}}=$ the fixed effect of herd-year season of calving (73 levels);

$\mathrm{P}_{1} \quad=$ the fixed effect of lactation number $(5$ levels representing the first 5 parities);

$\mathrm{AWP}_{\mathrm{m}}=$ Age within parity as a covariable;

$\mathrm{e}_{\mathrm{ijklmn}}=$ the residual random error term associated with observation $\mathrm{Y}$ assumed to be NID $\left(0, \sigma^{2}\right)$. Phenotypic parameters were estimated by the GLM and CORR procedures of SAS (SAS, 2000).

\section{RESULTS AND DISCUSSION}

Means, standard deviations (SD), minimums (Min.), maximums (Max.), and coefficients of variation (CV \%) for studied lactation traits $(\mathrm{kg})$ are given in Table 1. The mean of 305-d milk yield is comparable with that reported by Mourad et al. (1991), for Egyptian buffalo. The mean of 305-d milk yield (1402) is smaller than the corresponding estimates (1561, 1670 and $2287 \mathrm{~kg}$ ) reviewed by Mourad et al. (1990), Rosati and Van Vleck (2002) and Ahmad et al. (2009) working on different populations of buffaloes. Means of percentages for both fat and protein are within the range reported in the literature, which ranged from 5.0 to $13.3 \%$ for fat $\%$ and from 3.1 to $6.5 \%$ for protein\% as reported by Ceròn-Muñoz et al. (2002), Rosati and Van Vleck (2002) and Nazari et al. (2010) working on different populations of buffalo. Means for 305-d fat yield (FY) and 305-d protein yield (PY) obtained in the present study were much lower than their corresponding estimates given by Rosati and Van Vleck (2002) for the Italian buffalo (197 kg and $105 \mathrm{~kg}$, respectively). Kitchen (1981) found no change in fat content, yet total fat yield decreased because of a decline in milk production.

Table 1. Means, standard deviations (SD), minimums (Min.), maximums (Max.), and coefficients of variation (CV \%) of the lactation traits

\begin{tabular}{lccccc}
\hline Traits & Mean & SD & \multicolumn{2}{c}{ Range } & CV\% \\
\cline { 4 - 5 } & & & Min. & Max. & \\
\hline MY, kg & 1402 & 645 & 512 & 3983 & 36 \\
FY , kg & 94.9 & 46.5 & 30.0 & 342.1 & 39 \\
PY , kg & 53.6 & 24.2 & 20.0 & 187.8 & 36 \\
LSCC & 4.79 & 0.31 & 3.91 & 6.04 & 8 \\
\hline
\end{tabular}

${ }^{\mathrm{l}}$ MY: 305-d milk yield; FY: 305-d fat yield; PY: 305-d protein yield; and LSCC: lactation measure of SCC, corrected mean by (Wiggans and Shook, 1987).

The mean of LSCC (4.79) is comparable with that (4.74 - 4.83) reported by (ElBramony et al., 2004a; Saleh, 2005 and Youssef et al., 2009) working on Egyptian 
buffalo and Haile-Mariam et al. (2001) and Mrode and Swanson (2003) for Holstein Friesian cows.

The results of the analysis of variance revealed that all fixed effects (herd-yearseason of calving and age within parity) had a significant effect $(P<0.0001)$ on variation of all the studied traits. Similar results were reported by Mourad et al. (1990 and 1991), Badran et al. (2002) and El-Bramony et al. (2004a) for Egyptian buffalo; Ceròn-Muñoz et al. (2002) for Murrah buffalo and Wiggans and Shook (1987), Boettcher et al. (1992) and Haile-Mariam et al. (2001) for dairy cattle. Table 2 shows the effect of lactation order on the studied traits. All traits were affected $(P<0.001)$ by lactation order and tended to increase as lactation number increased. Similar results for milk yield traits were reported by Badran et al. (2002), Ceròn-Muñoz et al. (2002) and El-Bramony et al. (2004a) working on different populations of buffalo.

Results in table 2 show that LSCC significantly decreased in the fourth lactation compared with the first three lactations followed by a significant increase in the fifth one. The increase in SCC with parity (age) is attributed to the fact that older cows have a greater opportunity for exposure to mastitis causing pathogens than younger ones (Reneau, 1986 and Detilleux et al., 1997).

Table 2. Least squares means of the lactation traits by lactation

\begin{tabular}{lccccc}
\hline Traits $^{1}$ & \multicolumn{5}{c}{ Lactation } \\
\cline { 2 - 6 } & 1 & 2 & 3 & 4 & 5 \\
\hline MY, kg & $1254^{\mathrm{a}}$ & $1325^{\mathrm{b}}$ & $1457^{\mathrm{c}}$ & $1521^{\mathrm{d}}$ & $1636^{\mathrm{e}}$ \\
FY, kg & $85.7^{\mathrm{a}}$ & $88.1^{\mathrm{b}}$ & $100.1^{\mathrm{c}}$ & $105.1^{\mathrm{d}}$ & $110.0^{\mathrm{e}}$ \\
PY, kg & $51.1^{\mathrm{a}}$ & $52.9^{\mathrm{b}}$ & $56.7^{\mathrm{c}}$ & $58.2^{\mathrm{d}}$ & $61.5^{\mathrm{e}}$ \\
LSCC & $4.81^{\mathrm{a}}$ & $4.80^{\mathrm{a}}$ & $4.78^{\mathrm{a}}$ & $4.70^{\mathrm{b}}$ & $4.88^{\mathrm{c}}$ \\
\hline
\end{tabular}

Abcde: Means within rows with different superscript differ significantly $(\mathrm{p}<0.05)$.

${ }^{1}$ See abbreviation in table 1.

\section{Heritabilities:}

Heritability estimates for 305-d MY, 305-d FY and 305-d PY were 0.16, 0.12 and 0.15 , respectively as listed in Table3. Estimates were comparable with these reported by Rosati and Van Vleck (2002) for Italian buffalo but lower than those reported by Duarte (2002) for buffaloes in Brazil. Mourad and Mohamed (1995) reported that heritability estimates for total milk yield ranged from 0.03 to 0.20 in the first five lactations with an average of 0.11 across lactations. El-Bramony et al. (2004b) reported heritability estimates for test day milk records ranging from 0.12 to 0.22 in the first three lactations. Heritability estimates ranged from 0.12 to 0.20 for 305-d in Holstein cows (Dematawewa and Berger, 1998 and Al-Seaf et al., 2007). Jensen et al. (2001) found that residual variance generally increased with parity. ElBramony et al. (2004b) found that permanent enviornmental and residual variances tended to increase toward the edges of the defined lactation trajectory.

Generally, estimates of heritability obtained in the present study are low despite the fact that the Egyptian buffalo has not gone through intense genetic selection that could result in eroding the additive genetic variance. 
Table 3. Estimates of heritability $\left(h^{2}\right)$, repeatability $(r)$ and their standard errors of the lactation traits

\begin{tabular}{lcccc} 
Traits $^{1}$ & $\mathrm{~h}^{2}$ & SE & $\mathrm{r}$ & SE \\
\hline MY & 0.16 & 0.03 & 0.52 & 0.02 \\
FY & 0.12 & 0.01 & 0.50 & 0.02 \\
PY & 0.15 & 0.03 & 0.51 & 0.02 \\
LSCC & 0.27 & 0.03 & 0.38 & 0.02
\end{tabular}

${ }^{1}$ See abbreviation in table 1

Heritability estimate for LSCC in this study is within the range of estimates obtained when working with test day records for the same population El-Bramony et al. (2004b). Estimates reported in the literature for heritability of SCC (LSCC) ranged from 0.12 to 0.39 (Kadarmideen and Pryce, 2001; De Ross et al., 2003 and Weller and Ezra, 2004) for dairy cattle. Coffey et al. (1985) found a dramatic increase of estimates $(0.10$ to 0.29$)$ between $2^{\text {nd }}$ and $3^{\text {rd }}$ and later lactations. Heritability estimates for LSCS tended to increase as lactation number increased (Da et al., 1992). El-Bramony et al. (2004b) reported that there were lower variances (genetic, permanent environmental and residual) in $2^{\text {nd }}$ and $3^{\text {rd }}$ lactations. HaileMariam et al. (2001) stated that the increase in heritability with stage of lactation was accompanied by a large decrease in environmental and residual variances. De Ross et al. (2003) explained that other factors rather than genes (dry period and calving process) may be responsible for these results.

Repeatability estimates for milk yield traits ranged from 0.50 to 0.52 (Table3). These estimates are relatively higher than the estimates reviewed by Mourad et al. (1991), Tekerli et al. (2001) and Nazari et al. (2010) for different populations of buffalo that were in the range from 0.41 to 0.48 . This could be a result of the increase of cow variance and the decrease of residual variance with age. Dematawewa and Berger (1998) reported comparable estimates of repeatability for 305-d MY, 305-d FY and 305-d PY being 0.42, 0.41 and 0.41 , respectively for Holstein dairy cows.

Repeatability estimate for LSCC ranged from 0.32 to 0.45 (Da et al., 1992; Schutz et al., 1994 and Kadarmideen and Pryce, 2001) for dairy cattle. Heritability and repeatability estimated for LSCC in this study ( 0.27 and 0.38 , respectively) are within the range of estimates found in the literature for dairy cattle. Therefore, recommendations similar to those practiced for dairy cows, such as maintenance of hygienic conditions and the culling of sires on genetic basis when their daughters are predisposed to high SCC, are also recommended for dairy buffaloes to improve udder health.

\section{Phenotypic and genetic correlations:}

Phenotypic and genetic correlations were positive, nearly equal unity between milk yield traits (Table 4). This means that a genetic program to select for any of them would result in a favorable genetic response in the others. Similar estimates for genetic correlations between MY and both of FY (0.88) and PY (0.95) were reported by Rosati and Van Vleck 2002 for Italian buffalo. Duarte, (2002) estimated a genetic correlation between FY and PY of 0.88 for buffalo in Brazil. The corresponding 
estimates for dairy cows, ranged from 0.69 to 0.92 as given by Dematawewa and Berger (1998) and Kadarmideen et al. (2003).

Table 4. Phenotypic correlation coefficients (above the diagonal) and genetic correlations (below the diagonal) among lactation traits

\begin{tabular}{lcccc}
\hline Traits $^{1}$ & MY & FY & PY & LSCC \\
\hline & & 0.96 & 0.96 & -0.02 \\
0.99 & & 0.95 & 0.01 \\
0.99 & 0.98 & & -0.03 \\
-0.29 & -0.26 & -0.28 & \\
\hline & & & \\
\hline
\end{tabular}

${ }^{1}$ See abbreviations in table 1, standard errors of genetic correlations ranged from 0.16 to 40 .

LSCC had very weak and negative phenotypic correlations with both MY (-0.02) and PY (-0.03) with almost no correlation with FY (0.01). In general, phenotypic correlations found in the literature of SCC and milk yield traits for dairy cattle were weak and negative ranging between -0.23 to -0.05 (Kennedy et al., 1982 and Schutz et al., 1990). A positive but also weak genetic correlation (0.14) was reported between SCC and milk yield traits (milk, fat, and protein) by Mrode and Swanson (1996). Genetic correlations between yield traits and LSCC were moderate to low ranging from -0.32 to 0.24 (Schutz et al. 1990; Jamrozik et al., 1998 and Al-Seaf et al., 2007). Schutz et al. (1990) and Jamrozik et al. (1998) stated that LSCC had small and positive genetic correlation between $305-\mathrm{d}$ milk in the $1^{\text {st }}$ lactation and negative in $2^{\text {nd }}$ and $3^{\text {rd }}$ lactations. This result may be due to culling in the $1^{\text {st }}$ lactation on the bases of mastitis and production. Negative estimates for genetic correlation in later parities may be due to different genetic factors that influence milk and lactation mean SCS in first and later parities (Banos and Shook 1990).

Negative genetic associations between milk yield traits and LSCC (Table 4) are considered to be favorable, suggesting no antagonism between improvement of milk yield traits and udder health.

\section{CONCLUSION}

The positive and high genetic and phenotypic correlations (nearly equal unity) between lactation yield traits (milk, fat and protein) means that a genetic program to select for any of them would result in a favorable genetic response in the others. The low genetic correlations of lactation somatic cell count (LSCC) with milk yield traits indicate that a selection program to improve milk yield traits is not expected to result in a negative effect on udder health.

\section{ACKNOWLEDGEMENT}

The authors are grateful to Dr. E.S.E. Galal, Prof. of Animal Breeding, Ain Shams Univeristy, for his helpful comments and criticism of the work. 


\section{REFERENCES}

Ahmad, M., A. Zurwan, M. S. Azhar, M. Ishaq, M. E. Babar, A. Nadeem and M. Mushtaq, 2009. Performance of buffalo population using test day milk yield in progeny testing program of field areas. Pakistan J. Zool. Suppl. Ser., 9: 85-90.

Ali, A.K.A. and G.E. Shook, 1980. An optimum transformation for somatic cell concentration in milk. J. Dairy Sci. 63:487-490.

Al-Seaf. A., J. F. Keown and L.D. Van Vleck, 2007. Estimates of correlations among yield traits and somatic cell score with different models to adjust for bovine somatotropin effects on Holstein dairy cows. Genet. Mol. Res., 1: 67-78.

Badran, A. E., A. El-Barbary, A.E. Mahdy, and G.M. Assar, 2002. Genetic and nongenetic factors affecting the lifetime production traits in Egyptian buffaloes. Buffalo J. 2:235-241.

Banos, G. and G. E. Shook, 1990. Genotype by environment interaction and genetic correlations among parities for somatic cell count and milk yield. J. Dairy Sci., 73:2563-2573.

Barillet, F., 1985. Amélioration génétique de la composition de lait des brebis. L' exemple de la race Lacaune. Ph.D. Diss., Inst. Natl. Rech. Agron., Paris-Drignon, France. Cited by EL-Saied U.M., J.A.Carriedo, L.F. de la Fuente and F. San Primitivo, (1999). J. Dairy Sci., 82:639-644.

Boettcher, P. J., L. B. Hansen, P. M VanRaden. and C. A. Ernst, 1992. Genetic evaluation of Holstein bulls for somatic cells in milk of daughters. J. Dairy Sci., 75:1127-1137.

Cerón-Muñoz, M., H. Tonhati, J. Duarte, J. Oliveira, M. Muñoz-Berrocal and H. Jurado-Gámez, 2002. Factors affecting somatic cell counts and their relations with milk and milk constituent yield in Buffaloes. J. Dairy Sci., 85: 2885-2889.

Coffey, E. M., W.E. Vinson and R.E. Pearson, 1985. Heritabilities for lactation average of somatic cell counts in first, second, and third or later parities. J. Dairy Sci., 68: 3360-3362.

Coffey, E. M., W.E. Vinson, and R. E Pearson, 1986. Potential of somatic cell concentration in milk as a sire selection criterion to reduce Mastitis in dairy cattle. J. Dairy Sci., 69:2163-2172.

Da, Y., Grossman, M. Misztal, I. and G. R. Wiggans, 1992. Estimation of genetic parameters for somatic cell score in Holsteins. J. Dairy Sci., 75:2265-2271.

De Ross, A. P. W., Harbers, A. G. F. and De Jong, G. 2003. Genetic parameters of test-day somatic cell score estimated with a random regression model. Proc. Interbull Technical workshop, Rome, Italy, August 28-30, Bulletin no 31, 79-101.

Dematawewa, C.M.B. and P. J. Berger, 1998. Genetic and phenotypic parameters for 305-day yield, fertility, and survival in Holsteins. J. Dairy Sci., 81:2700-2709.

Detilleux, J., P. Leroy, and D. Volckaert, 1997. Alternative use of somatic cell counts in genetic selection for mastitis resistance. Proc. Intl. Workshop on GIFT in Cattle, Health, Uppsala, Sweden. Interbull Bull. 15:34-44.

Duarte, J. M., 2002. Parametros genéticos e fenotipicos da producao e constituintes do leite e tendencia genetica da producao de leite em bubalinos. Master's. thesis, Facultad Estadual Paulista, Jaboticabal (cited by Seno et al., 2006).

El-Bramony, Manal M., A. A. Nigm, Kawthar A. Mourad and U. M. El-Saied, 2004a. Factors Affecting Somatic Cell Counts and their Relations with Milk 
Yield in Egyptian Buffalo. 12th Scientific Conference, Egyptian Society of Animal Production. Mansoura University, Egypt, November 29-December 3, 2004. Egyptian J. Anim. Prod., 41 (Suppl. Issue): 61-71.

El-Bramony, Manal M., A. A. Nigm, Kawthar A. Mourad, M.A.M. Ibrahim and U.M. El-Saied, 2004b. Estimation of genetic parameters for test day milk yield and somatic cell count in the first three lactations of Egyptian buffalo using random regression. 12th Scientific Conference, Egyptian Society of Animal Production. Mansoura University, Egypt, November 29-December 3, 2004. Egyptian J. Anim. Prod., 41 (Suppl. Issue): 15-31.

Emanuelson, U., B. Danell and J. Philipsson, 1988. Genetic parameters for clinical mastitis, somatic cell counts, and milk production estimated by multiple-trait restricted maximum likelihood. J. Dairy Sci., 71:467-476.

Groeneveld, E. and L. A. García Cortés, 1998. VCE 4.0, a (co)variance components package for frequentists and Bayesians. Proc.6th World Congress on Genetics Applied to Livestock production. Vol. 27, pp.455-456.

Haile-Mariam, M., Goddard, M. E. and P. J. Bowman, 2001. Estimates of genetic parameters for dairy somatic cell count of Australian daily cattle. J. Dairy Sci., 84:1255-1264.

Heringstad, B., Y.M. Chang, D. Gianola and G. Klemetsdal, 2003. Genetic analysis of longitudinal trajectory of clinical mastitis in first-lactation Norwegian cattle. J. Dairy Sci., 86:2676-2683.

Jamrozik, J., L.R. Schaeffer and F. Grignola, 1998. Genetic parameters for production traits and somatic cell score of Canadian Holstein with multiple trait random regression model. Proc. 6th World Congr. Genet. Appl. Livest. Prod., January 11-16. Armidale, New South Wales Australia, 23:303-306.

Jensen, J., J. Jamrozik and L. R. Schaeffer, 2001. Modeling production in all lactations in dairy cattle using random regression test day models. Book of Abstract proc. 52nd Annu. Mtg. of the EAAP. August 26-29 Budapest, 2001.

Kadarmideen, H. N. and J. E. Pryce, 2001. Genetic and economic relationships between somatic cell count and clinical mastitis and their use in selection for mastitis resistance in dairy cattle. Anim. Sci., 73:19-28.

Kadarmideen, H.N., R. Thompson, M.P. Coffey and M. A. Kossaibati, 2003. Genetic parameters and evaluations from single-and multiple-trait analysis of dairy cow fertility and milk production. Livest. Prod. Sci., 81: 183-195.

Kennedy, B. W., Sethar, M. S., J. E. Moxley and B. R. Downey, 1982. Heritability of somatic cell count and its relationship with milk yield and composition in Holsteins. J. Dairy Sci. 65:843-847.

Kitchen, B. J., 1981. Review of progress of dairy science: Bovine mastitis: milk compositional changes and related diagnostic test. J. Dairy Res., 48:167-188.

Mourad, Kawthar A. and E.A. Afifi and L.H. Bedeir, 1990. Non genetic factors influencing milk production traits in Egyptian buffaloes. Egyptian J. Anim. Prod., 27 (1): 1-18.

Mourad, Kawthar A. and M. M. Mohamed and A. S. Khattab, 1991. Genetic parameters for milk production traits in a closed herd of Egyptian buffaloes. Egyptian J. Anim. Prod., 28 (1): 11-20. 
Mourad, Kawthar A. and Mahasen M. Mohamed, 1995. Genetic and phenotypic aspects of milk yield traits and reproductive performance of Egyptian buffalo. Egyptian J. Anim. Prod., 32 (2): 125-137.

Mrode, R. A. and G. J. T. Swanson, 2003. Estimation of genetic parameters for somatic cell count in the first three lactations using random regression. Livest. Prod. Sci. 79: 239-247.

Mrode, R.A. and G. J.T. Swanson, 1996. Genetic and statistical properties of somatic cell count and its suitability as an indirect means of reducing the incidence of mastitis in dairy cattle. Anim. Breed. Abstr., 64:847-857.

Nazari, M., J. Fayazi, S. Tabatabaei, A. Aghaei and M. Mamoei, 2010. Investigation of the genetic and phenotypic potentional of productive traits using the uni and multiple traits animal model in river buffalo. J . Anim. Vet. Adv., 10: 1479-1481.

Reneau, J. K., 1986. Effective use of dairy herd improvement somatic cell counts in mastitis control. J. Dairy Sci., 69:1708-1720.

Rodriguez-Zas, S. L., D.Gianola, and G. E. Shook, 2000. Evaluation of models for somatic cell score lactation patterns in Holsteins. Livest. Prod. Sci., 67:19-30.

Rosati, A. and L. D. Van Vleck, 2002. Estimation of genetic parameters for milk, fat, protein and mozzarella cheese production for the Italian river buffalo Bubalus bubalis population. Livest. Prod. Sci., 74:185-190.

Saleh, I. A., 2005. Studies on milk production of buffaloes. Ph. D. thesis, Fac. of Agric., Mansoura Univ., Egypt.

Schutz, M. M., L. B. Hansen, G.R. Steuernagel, J. K. Reneau and A. L. Kuck, 1990. Genetic parameters for somatic cells, protein, and fat in milk of Holsteins. J. Dairy Sci., 73: 494-502.

Schutz, M. M., P. M. Vanraden and G. R. Wiggans, 1994. Genetic variation in lactation mean of somatic cell scores for six breeds of dairy cattle. J. Dairy Sci., 77:284-293.

Seno, L.O., V.L. Cardoso and H. Tonhati, 2006. Responses to selection for milk traits in dairy buffaloes. Genet. Mol. Res., 4: 790-796.

Tekerlia, M., M. Kucukkebabci, N.H. Akalin, S. Kocak 2001. Effects of environmental factors on some milk production traits, persistency and calving interval of Anatolian buffaloes. Livest. Prod. Sci., 68: 275-281.

Weller, J. I. and E. Ezra, 2004. Genetic analysis of the Israeli Holstein Dairy cattle population for production and nonproduction traits with a multitrait animal model. J. Dairy Sci., 87:1519-1527.

Wiggans, G.R. and G. E. Shook, 1987. A lactation measure of somatic cell count. J. Dairy Sci., 70:2666-2672.

Youssef, M. M., Manal, M. El-Bramony, Azza M. El-Baz and M. A. El-Sherbieny, 2009. Relationship between somatic cell count in milk and intrammary infection in Egyptian buffaloes. Egypt. vet. med. Assoc., 69:197-207. 


\section{تحليل وراثي لتعدد الخلايا الجسدية وصفات إنتاج اللبن في الجاموس المصري ؛ منال محمد البرمونى، إيهاب عبد العزيز جبريل، ست الحابيب شلبي}

معهل بحوث الإنتاج الحيوانس، مركز البحوث النزاعية، وزارة الزراعة وإستصلاح الأرضي، الدقى، جيزه،

أستهدفت الدراسـة بحث العلاقة بين إنتاج اللبن والدهن والبروتين مـع تعداد الخلايا الجسدية فى اللبن

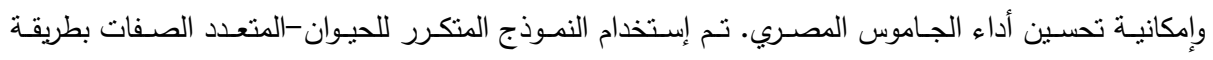

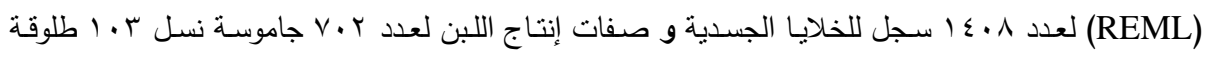

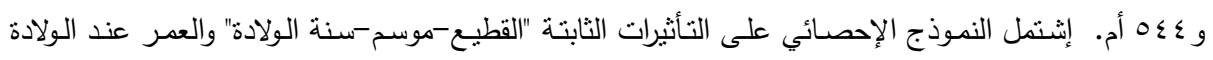

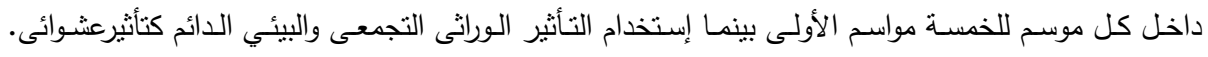

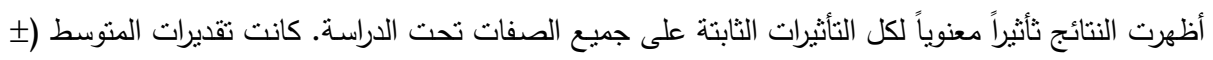

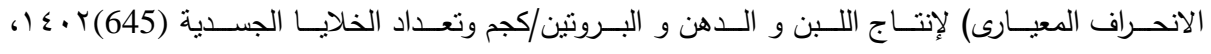

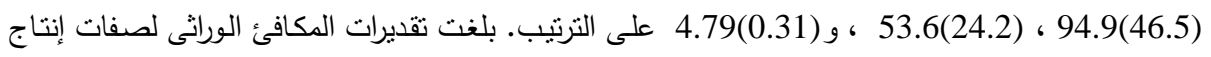

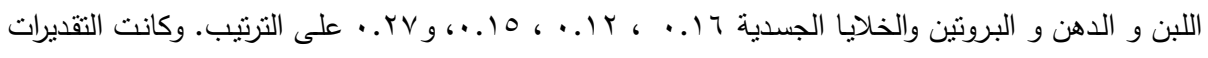

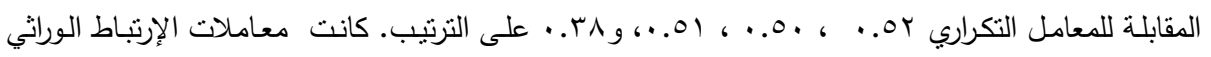

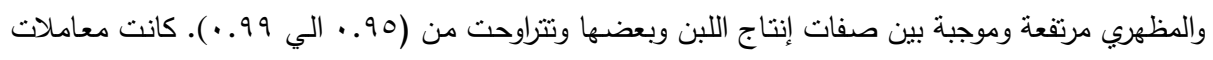

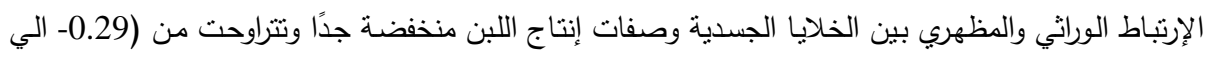

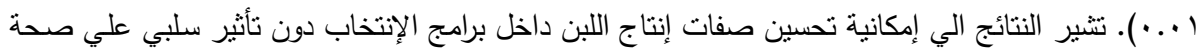

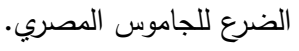

